\title{
Total phenolic content and antioxidant activity of ginger extract and SNEDDS with eel fish bone oil (Anguilla spp.)
}

\author{
IMAS IFRIAN WIJAYANTI ${ }^{1, v}$, AGUNG BUDIHARJO ${ }^{1,2, v v}$, ARTINI PANGASTUTI ${ }^{1,2,}$ FEA PRIHAPSARA ${ }^{3, v v v,}$ \\ ANIF NUR ARTANTI ${ }^{3}$ \\ ${ }^{1}$ Bioscience Graduate Program, Universitas Sebelas Maret. Jl. Ir. Sutami 36A Surakarta 57 126, Central Java, Indonesia. Tel./fax.: +62-856- \\ 786686168/+61-857-43210550, `email: imasifriani@gmail.com \\ ${ }^{2}$ Department of Biology, Faculty of Mathematics and Natural Sciences, Universitas Sebelas Maret. Jl. Ir. Sutami 36A Surakarta 57 126, Central Java, \\ Indonesia." "email : budiharjo_ag@yahoo.com \\ ${ }^{3}$ Department of Pharmacy, Faculty of Mathematics and Natural Sciences, Universitas Sebelas Maret. Jl. Ir. Sutami 36A Surakarta 57 126, Central Java, \\ Indonesia. ${ }^{\text {} \rightsquigarrow}$ email: feapri87@gmail.com
}

Manuscript received: 17 June 2018. Revision accepted: 14 August 2018.

\begin{abstract}
Wijayanti II, Budiharjo A, Pangastuti A, Prihapsara F, Artanti AN. 2018. Total phenolic content and antioxidant activity of ginger extract and SNEDDS with eel fish bone oil (Anguilla spp.). Nusantara Bioscience 10: 164-169. Aims of this study were to measure phenolic content of ginger (Zingiber officinale) and to observe the comparison of antioxidant activity between pure ginger extract and ginger extract in SNEDDS (Self Nanoemulsifying Drug Delivery System) with bone of eel fish oil (Anguilla spp.) as a conductor. Analysis was done based on IC50 value using DPPH (2,2 diphenyl-1-picrylhydrazyl) method and activity of Superoxide Dismutase (SOD) in vivo using Adrenochrome Assay. Determination of total phenolic content of ginger extract was measured by UV/Vis Spectrophotometric using Folin-Ciocalteau reagents then the absorbances were measured at wavelength $756 \mathrm{~nm}$. Calculation of $\mathrm{IC}_{50} \mathrm{DPPH}$ of the ginger extract and SNEDDS were measured using spectrophotometer UV/Vis at $517 \mathrm{~nm}$ wavelength. Measurements of SOD was based on the ability of SOD inhibit spontaneous auto reduction of epinephrine using Adrenochrome Assay at 12 male Wistar rats that divided into 4 treatment groups with 3 replicates for each group. Total phenolic content of ginger extract from 3 replications were $4,8519 \pm 0,037 \mu \mathrm{g} / \mathrm{mL}$ equivalent with gallic acid standard solutions (GAE) or 485,1847 $\pm 3,7045 \mathrm{mgGAE} / 100 \mathrm{~g}$ dry weight. Antioxidant scavenging activity by DPPH assay of ginger was higher than SNEDDS. IC 50 of ginger was $385.4 \mathrm{mg} / \mathrm{mL}$, and IC50 of SNEDDS was $428.4 \mathrm{mg} / \mathrm{mL}$. The result of descriptive analysis of Kruskal Wallis of SOD activity assay indicated significant differences between treatment groups $(\mathrm{P}=0.001(\mathrm{P}<0.05)$ ). SOD activity test performed in vivo showed that ginger extract made into SNEDDS system with eel fish oil used as the conductor has a significant influence compared with ginger extract group.
\end{abstract}

Keywords: Anguilla, DPPH, eel fish, phenolic content, SOD, SNEDDS, Zingiber officinale

\section{INTRODUCTION}

Oxidative stress is a condition where the formation of Reactive Oxygen Species (ROS) and long-lasting antioxidant defense systems are imbalanced (Juranek and Bezek 2005; Ahmad 2013). One of the results of the reaction between free radicals and epithelial cell phospholipid membranes is malondialdehyde (MDA). MDA formation can be prevented by antioxidant compounds, Superoxide Dismutase (SOD), catalase (CAT), and Glutathione Peroxidase (GPx). However, the first body reserves in overcoming oxidative stress are SOD (Rajkumar et al. 2008). So that SOD is very important in the body to scavenge free radicals.

The use of ginger in certain doses is known to have high antioxidant activity, which has been widely tested to counteract various types of free radicals and protect cell membrane lipids from oxidation activity. Several studies using rat test animals, showed that ginger can decrease lipid peroxidation activity as well as improve the performance of antioxidant enzymes and serum glutathione. Other studies found an antioxidant effect of ginger is equivalent to ascorbic acid. Research conducted on hypertensive test animals showed that the use of ginger at certain doses can lower blood pressure. Ginger causes vasodilation in mice and rabbits, and inhibits calcium channel-blocking activity as verapamil (Nicoll and Henein 2009).

The compounds in ginger have been proven to be one of the antioxidant agents that inhibit ROS, which become one of the causes of various diseases. However, many chemical compounds have low solubility in water despite high intestinal permeability, so that compounds are classified into class II drugs according to Biopharmaceutical Classifications System (BCS). The current lipid-based drug delivery system has been widely developed as it demonstrates the ability to increase the bioavailability of drug compounds. One type of lipid-based drug delivery is SNEDDS (Self-Nano Emulsifying Drug Delivery System), which is a mixture of oils, surfactants, co-surfactants, and drugs that can form emulsions in water solvents with nanometer-sized droplets when it is dissolved in liquid medium (Patel et al. 2010; Christophersen 2014).

In this study, the SNEDDS system was prepared by mixing ginger extract with eel bone oil together with surfactant and co-surfactant to reduce surface tension so 
that the two substances can be completely mixed. Ginger extract made into SNEDDS is expected to optimize the performance of the compound in ginger and form a nanometer-sized emulsion to enhance bioavailability.

The delivery used in SNEDDS is eel bone oil. Utilization of fish bone is expected to reduce the effect of fish waste obtained from the existing waste disposal in eel fish ponds in Surakarta. Eel fish (Anguilla bicolor) is a very popular fish consumption in many countries especially Japan, China, Germany, and France. It contains vitamin A, B1, B2, B6, C, D, albumin protein, DHA (Docosahexaenoic acid) and EPA (Eicosapentaenoic acid) that is better known as omega-3, as well as some other minerals (Rovara et al. 2010).

Eel fish is one of the cultivated fish that has high economic value. Sidat has a high nutrient content. Eel energy content reached $270 \mathrm{kcal} / 100 \mathrm{~g}$, vitamin A content of sidat reached $4700 \mathrm{IU}-/ 100 \mathrm{~g}$ seven times more than chicken eggs, 45 times that of cow's milk. Vitamin B1 of eel equivalent to 25 times of vitamin B1 content of cow's milk. While vitamin B2 eel is equal to 5 times of vitamin B2 content of cow's milk. Compared with salmon, eel contains DHA (Docosahexaenoic acid, for child growth) of $1,337 \mathrm{mg} / 100 \mathrm{~g}$ while salmon is only $820 \mathrm{mg} / 100 \mathrm{~g}$ or mackerel $748 \mathrm{mg} / 100 \mathrm{~g}$. Sidat contains EPA (Eicosapentaenoic Acid) of $742 \mathrm{mg} / 100 \mathrm{~g}$ while salmon is only $492 \mathrm{mg} / 100 \mathrm{~g}$ or mackerel $409 \mathrm{mg} / 100 \mathrm{~g}$ (Baedah 2010).

Cardiovascular protection as effects of fish oil and polyunsaturated fatty acids (PUFA) can make lower blood pressure and prevent the development of hypertension. Effects of Cardiovascular Protective by fish oil due to 2 fatty acids contained in fish oil include-Eicosapentaenoic acid (EPA) and Docosahexaenoic acid (DHA). Dietary supplements contained in both these fatty acids may provide cardiovascular protection effects and lower blood pressure. DHA is known to be effective in lowering blood pressure and cardiovascular disease risk factors (Frenoux et al. 2001).

Antioxidant status is a factor associated with several diseases such as cardiovascular pathology. The concentration of oxidized LDL plasma is strongly associated with cardiovascular disease. This LDL is destroyed by macrophage and contributes to the formation of cell formation, accumulation in the vessel wall and the development of atherosclerosis. PUFAs such as GLA, EPA, and DHA inhibit lipid hypersensitivity and peroxidation that promote atherogenic particles that neutralize the effects of blood pressure, platelet metabolism and lipid profiles (Fernoux et al. 2001; Inoue et al. 2015).

The presence of eel bone oil as a conductor in SNEDDS ginger extract is expected to optimize the performance of phenolic compounds of ginger in its utilization as an antioxidant agent. Thereafter comparing the antioxidant activity of pure ginger extract with ginger extract in SNEDDS with bone of eel fish oil as a conductor. Antioxidant activity was measured by DPPH (2,2 diphenyl1-picrylhydrazyl) assay and superoxide dismutase enzyme activity with Adrenochrome Assay.

\section{MATERIALS AND METHODS}

\section{Extraction of ginger and SNEDDS preparation}

Extraction of ginger was prepared by dissolved $100 \mathrm{~g}$ of ginger powder into $500 \mathrm{~mL}$ of ethanol $96 \%$ for 3 days, then the extract solution was filtered for evaporation using a rotary evaporator to obtain a thickened ginger extract. Then the preparation of ginger SNEDDS with eel fish bone oil was prepared by mixed $1000 \mathrm{mg}$ of ginger extract into 0.56 $\mathrm{g}$ of eel fish bone oil, $3.89 \mathrm{~g}$ of tween 80 as surfactant and $0.56 \mathrm{~g}$ of PEG 400 as cosurfactant. It was then mixed in vortex for 2 minutes, sonication for 15 minutes and water bath for 10 minutes at $45^{\circ} \mathrm{C}$.

\section{Measurement of total phenolic content}

Measurement of total phenolic content by colorimetric assay based on procedure of Chun et al. (2003) and Malik et al. (2015) with few modifications using gallic acid (GAE) as a standard. (i) Preparation of $\mathrm{Na}_{2} \mathrm{CO}_{3} 7 \%$. As much as $3.5 \mathrm{~g} \mathrm{Na}_{2} \mathrm{CO}_{3}$ was diluted into aquabidest until 50 $\mathrm{mL}$. (ii) Preparation of gallic acid. As much as $1000 \mathrm{ppm}$ of gallic acid was made by diluted $10 \mathrm{mg}$ of gallic acid into methanol p.a until $10 \mathrm{~mL}$. From this stock solution, as much as $2,5 \mathrm{~mL}$ was taken into methanol until $25 \mathrm{~mL}$ to make $100 \mathrm{ppm}$ of gallic acid solution. From this solution series of amount taken solution i.e 1, 2, 3, 4, $5 \mathrm{~mL}$ was added into methanol p.a until $10 \mathrm{~mL}$ for each so that their concentrations were 10,20,30, 40 and $50 \mathrm{ppm}$ of gallic acid solutions. (iii) Measurement of gallic acids absorbances. Each concentration of gallic acid was added into $0.4 \mathrm{~mL}$ Folin-Ciocalteau reagent, which were then mixed and incubated for 4-8 minutes. After 4-8 minutes, as much as $4 \mathrm{~mL}$ of $\mathrm{Na}_{2} \mathrm{CO}_{3} 7 \%$ was added into each solution, followed by incubation for 90 minutes. Determinations of gallic acid solutions absorbances were using UV/Vis spectro-photometric at wavelength $756 \mathrm{~nm}$. The calibration curve was made from absorbances measuring of gallic acid standard solutions.

Preparation of ginger solution extract was made by adding $10 \mathrm{mg}$ of extract into $10 \mathrm{~mL}$ of methanol p.a. Determination of total phenolic content of ginger extract was measured using UV/Vis Spectrophotometric by adding $1 \mathrm{~mL}$ of ginger extract into $0,4 \mathrm{~mL}$ Folin-Ciocalteau reagent then they were mixed and incubated for 4-8 minutes. After 4-8 minutes, $4 \mathrm{~mL}$ of $\mathrm{Na}_{2} \mathrm{CO}_{3} 7 \%$ was added into the mixture and incubated for 90 minutes. The absorbances were measured at wavelength $756 \mathrm{~nm}$.

\section{Free radical scavenging activity determination}

DPPH was used for the determination of free radical scavenging activities based on Kwon and Kim (2003). As much as $1 \mathrm{~mL}$ of extract solutions and ginger SNEDDS solutions for different concentration (1000; 500; 250; 125; 62,5 ; and $31,25 \mu \mathrm{g} / \mathrm{mL}$ ) in test tube was added into $1 \mathrm{~mL}$ of $0,3 \mathrm{mM}$ DPPH in methanol. The mixtures were mixed and then incubated in a dark chamber for 30 minutes. The absorbances were measured at $517 \mathrm{~nm}$. The percentage of scavenging activity was calculated using formula:

$$
\% \text { scavenging activity }=\frac{A-B}{A} \times 100 \%
$$


Where:

A : Absorbance of control
B : Absorbance of sample

\section{Determination of superoxide dismutase activity}

In vivo preparation of the samples was done as follows: A total of 12 male Wistar rats were divided into 4 treatment groups with 3 replicates for each group. The groups were divided into a control group in which this group received no special treatment, the dex group was the group receiving $30 \mu \mathrm{g} / \mathrm{kg} \mathrm{B}$ dexamethasone injection daily for 18 days. Group 3 was given oral extract $200 \mathrm{mg} / \mathrm{kg}$ for 18 days, which were then injected with dexamethasone on days 518. Group 4 received SNEDDS orally at $300 \mu \mathrm{g} / \mathrm{kg}$ for 18 days, which were then injected with dexamethasone on days 5-18. The detailed schedule of in vivo treatment is presented in Table 1.

SOD activity was measured using Adrenochrome Assay method as an easy method which has a high sensitivity to measure SOD activity. Measurements based on the ability of SOD inhibit spontaneous auto reduction of epinephrine. Epinephrine solution in acidic state will be stable, but it will be spontaneously oxidized with the increase of $\mathrm{pH}$. Auto-oxidation occurs most rapidly accompanied by the formation of adrenochrome with linear velocity at $\mathrm{pH} 10.2$ and temperature $30^{\circ} \mathrm{C}$.

Determination of superoxide dismutase activity was measured based on Fatimah et al. (2010). As much as $1 \mathrm{~mL}$ of blood $50 \%$ of each replication were incubated at temperature of $37^{\circ} \mathrm{C}$ for 15 minutes, then they were centrifuged with acceleration $3000 \mathrm{rpm}$ for 5 minutes. Afterward, the pellet was washed off by $\mathrm{NaCl} 0,9 \%$ solutions and centrifuged with acceleration $3000 \mathrm{rpm}$ for 5 minutes. This part was done 3 times. As much as $500 \mu \mathrm{L}$ of supernatant was added into $800 \mu \mathrm{L}$ chloroform-ethanol (3:5), they were subsequently mixed for 1 minutes and centrifuged for 10 minutes. Supernatant was kept at the refrigerator for Blanko, As much as $2800 \mu \mathrm{L}$ buffer carbonate was added into $100 \mu \mathrm{L}$ aquadest and $100 \mu \mathrm{L}$ epinephrine. This mixing was then mixture and measured its absorbance at wavelength of $480 \mathrm{~nm}$ and at temperature $30^{\circ} \mathrm{C}$. For sample tube, as much as $5 \mu \mathrm{L}$ of sample was added into $2800 \mu \mathrm{L}$ buffer carbonate, $100 \mu \mathrm{L}$ aquadest and $100 \mu \mathrm{L}$ epinephrine, then the absorbance was measured at wavelength $480 \mathrm{~nm}$ at temperature $30^{\circ} \mathrm{C}$.

The percentage of SOD activity was calculated using formula:

$\%$ scavenging activity $=\frac{A-B}{A} \times 100 \%$
Where:

A : Absorbance of control

B : Absorbance of sample

Then the SOD activity was measured using formula:

$$
\text { SOD activity }=\frac{\% \text { Scavenging activity }}{50 \%} \times \mathrm{Fp}
$$

\section{RESULTS AND DISCUSSION}

\section{Phenolic content of ginger (Zingiber officinale) extract}

Measurement of Total Phenolic Content was done using gallic acid to create standard curve based on Ahmad et al. (2015). The absorbance of five gallic acid concentrations was measured at wavelength of $765 \mathrm{~nm}$. The results were then used to form regression curve and get the regression equation to measure the ginger phenolic content. The standard curve of gallic acid is presented in Figure 1. Ginger extract solution was measured at wavelength 756 $\mathrm{nm}$. The result was presented in Table 2 .

Table 1. Schedule and treatment groupings in vivo

\begin{tabular}{|c|c|c|c|c|c|}
\hline \multirow[t]{2}{*}{ Group } & \multicolumn{5}{|c|}{ Days- } \\
\hline & $1^{\text {st }}$ & $2^{\text {nd }}$ & $3^{\text {rd }}$ & $4^{\text {th }}$ & $5^{\text {th }}$ until $18^{\text {th }}$ \\
\hline Control (1) & \multicolumn{5}{|c|}{ Without treatment } \\
\hline Group 2 & \multicolumn{5}{|c|}{ Dexamethasone } \\
\hline Group 3 & Gir & ger ext & & & $\begin{array}{l}\text { ginger extract } 200 \\
\text { kg body weight }\end{array}$ \\
\hline Group 4 & SNEL & $\mathrm{DS}(30$ & $\mathrm{mg})$ & & SNEDDS $300 \mathrm{mg}$ \\
\hline
\end{tabular}

Note: dexamethasone on the group 3 and 4 is given as much as 30 $\mu \mathrm{g} / \mathrm{kg}$ body weight injection daily for 14 days. SNEEDS and ginger extract were given using intragastric tube

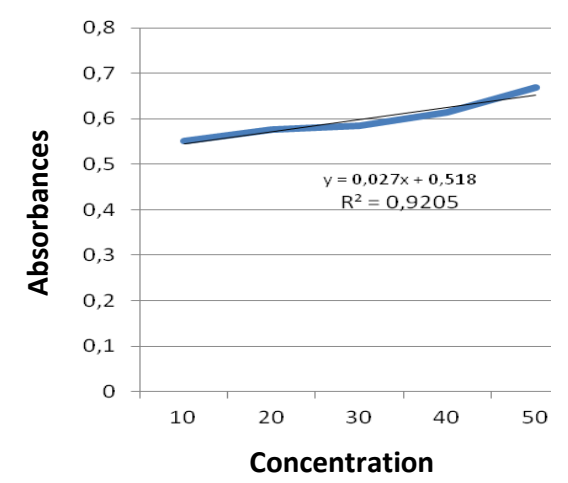

Figure 1. Regression curve of absorbance of gallic acid on concentration

Table 2. Result of total phenolic content of ginger solution

\begin{tabular}{llcr}
\hline Concentration & Absorbance & $\begin{array}{c}\text { Gallic acid equivalent standard } \\
(\boldsymbol{\mu g G A E} / \mathbf{m L})\end{array}$ & $\begin{array}{c}\text { Total Phenolic content } \\
(\mathbf{m g G A E} / \mathbf{1 0 0} \text { g dry weight) }\end{array}$ \\
\hline $1 \mathrm{mg} / \mathrm{mL}$ & 0.65 & 4.888889 & 488.889 \\
& 0.648 & 4.814815 & 481.480 \\
& 0.649 & 4.851852 & 485.185 \\
Mean & & 4.851852 & 485.1847 \\
SD & & 0.037037 & 3.7045 \\
\hline
\end{tabular}


Based on the regression curve, it showed that regression equation of gallic acid at concentration 10, 20, 30, 40, and $50 \mathrm{ppm}$ was $\mathrm{y}=0.027 \mathrm{x}+0.518$, which the standard solution of phenolic compound was linear between absorbances and concentrations with coefficient of correlation (r) was 0.9205. Result of measurement of phenolic content of ginger (Zingiber officinale Rosc) showed that it has phenolic content as much as $4.8519 \pm$ $0.037 \mu \mathrm{g} / \mathrm{mL}$ equivalent with gallic acid standard solutions (GAE) or $485.1847 \pm 3.7045 \mathrm{mgGAE} / 100 \mathrm{~g}$ dry weight.

\section{DPPH scavenging activity}

DPPH scavenging activity of ginger and SNEDDS was measured based on the formula to obtain the percentage of DPPH scavenging activity that was presented in Table 3.

DPPH scavenging activity of ginger and SNEDDS was made into a regression curve to obtain the regression equation used to measure $\mathrm{IC}_{50}$ between ginger and SNEDDS. The graph of the regression curve between ginger and SNEDDS can be seen in Figure 2.

Based on the regression graphic above, it showed that that antioxidant Scavenging activity by DPPH assay of ginger was higher than SNEDDS. $\mathrm{IC}_{50}$ was measured based on the regression equation of each ginger, and SNEDDS result of $\mathrm{IC}_{50}$ of ginger was $385.4 \mathrm{mg} / \mathrm{mL}$, and $\mathrm{IC}_{50}$ of SNEDDS was $428.4 \mathrm{mg} / \mathrm{mL}$. $\mathrm{IC}_{50}$ values denoted the concentration of the sample which is required to scavenge $50 \%$ DPPH free radicals. Higher $\mathrm{IC}_{50}$ values denoted lower antioxidant activities. It means that SNEDDS antioxidant activities based on DPPH assay was lower than pure ginger extract.

\section{Superoxide dismutase activity}

SOD activity was measured with adrenochrome assay. It showed that the activity of SOF of SNEDDS was higher than other groups. The activity of SOD is presented in Figure 3.

Control group was the group of rats without any special treatment, then the dexamethasone group was the group of rats which got dexamethasone injection subcutaneously 30 $\mu \mathrm{g} / \mathrm{kg}$ body weight for 18 days. Ginger group got ginger extract orally for 18 days ( $50 \mathrm{mg} / \mathrm{kg}$ body weight) and dex injection for 14 days. Then the SNEDDS group got SNEDDSS orally for 18 days (50 mg/kg body weight) and dex injection for 14 days.

The graph above showed that the normal control group had a SOD activity of \pm 0.646 units $/ \mathrm{mL}$. The dexamethasone group had the lowest SOD activity of \pm 0.065 units $/ \mathrm{mL}$. In the ginger group, mice treated with dexamethasone and treated with oral ginger extract increased the activity of SOD to \pm 0.326 units $/ \mathrm{mL}$. In the treatment group with dexamethasone and SNEDDS treatment, the activity of SOD increased to \pm 1.21 units $/ \mathrm{mL}$.

The result of descriptive analysis of Kruskal Wallis expressed that Asymp sig value $\mathrm{P}=0.001 \quad(\mathrm{P}<0.05)$ indicated that there were significant differences between treatment groups. SOD activity test performed in vivo showed that ginger extract made into SNEDDS system with eel fish oil as the conductor has a significant influence compared with ginger extract group.
Table 3. Percentage of DPPH scavenging activity of SNEDDS and ginger

\begin{tabular}{lcc}
\hline $\begin{array}{c}\text { Concentration } \\
(\boldsymbol{\mu} \mathbf{g} / \mathbf{m L})\end{array}$ & $\begin{array}{c}\text { Activity of } \\
\text { SNEDDS }\end{array}$ & $\begin{array}{c}\text { Activity of } \\
\text { ginger }\end{array}$ \\
\hline & & \\
31.25 & $37 \%$ & $37 \%$ \\
62.5 & $37 \%$ & $45 \%$ \\
125 & $44 \%$ & $65 \%$ \\
250 & $62 \%$ & $83 \%$ \\
500 & $79 \%$ & $94 \%$ \\
1000 & $90 \%$ & $94 \%$ \\
\hline
\end{tabular}

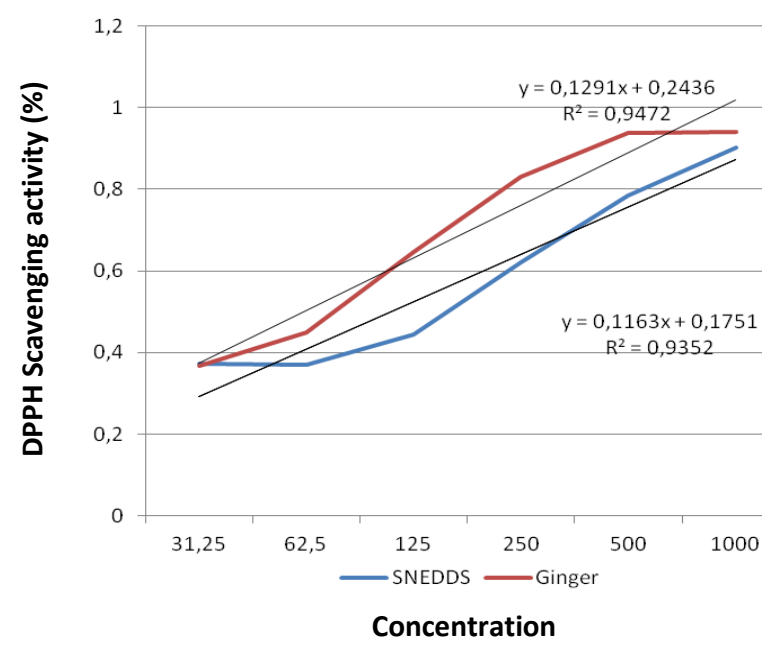

Figure 2. Regression curve of ginger and SNEDDS activity on $\mathrm{DPPH}$

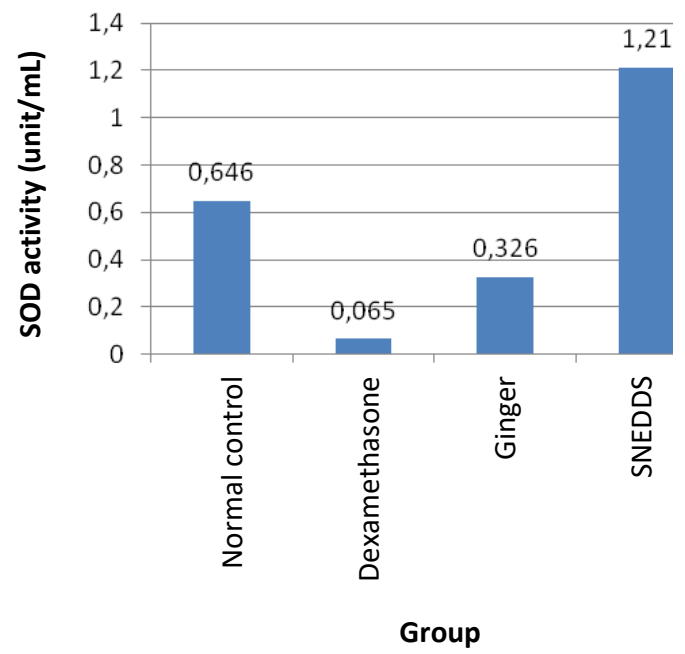

Figure 3. Activity of superoxide dismutase on dexamethasoneinduced rat 


\section{Discussion}

Aims of the study were to measure the total phenolic content of ginger (Zingiber officinale) extracted using $96 \%$ ethanol solvent. The ethanol solvent is chosen because of the ability of ethanol to bind secondary metabolite compounds in the sample (Harborne 1998). The result of the measurement of phenolic content showed a high yield of $4.85 \mathrm{mg} / \mathrm{mL}$ equivalent with standard solution of gallic acid. The compounds in ginger have been proven to prevent the causes of various diseases (Nicoll and Henein 2009; Akinyemi et al. 2014).

Ginger extract in SNEDDS with eel fish oil conductor can form nanoparticle-sized emulsion droplets in the gastrointestinal tract so that in the same dose of extract, the ability of cells to absorb drug compounds is greater to provide optimum efficiency. The ability of SNEDDS drug delivery systems is expected to optimize the absorption of drugs in the gastrointestinal tract to optimize the effects of compounds in small doses.

The antioxidant activity of ginger extract and SNEDDS was measured using DPPH acceleration showed that $\mathrm{IC}_{50}$ ginger was lower than SNEDDS. It showed that in vitro assay of the pure ginger extract activity is higher than SNEDDS. The ginger extract in SNEDDS has a lower concentration than pure ginger extract and therefore in vivo tests need to be done. In vivo tests were performed to determine the antioxidant activity based on Superoxide dismutase enzyme activity with adrenochrome assay. Dexamethasone is used as a negative ROS trigger in control group. The association of Dexamethasone with oxidative stress has led to study to delineate the specific pathways of vascular superoxide generation that are likely to contribute to the pathogenesis of DEX-HT. The specific roles of NAD (P)H oxidase, xanthine oxidase, uncoupled eNOS and mitochondria were evaluated by inhibiting these pathways in dexamethasone-hypertensive rats (Ong et al. 2014).

SOD (Superoxide Dismutase) is one of the enzymatic antioxidants. There are 3 known types of SOD, CuZnSOD, MnSOD found in humans and synthesized in the endoplasmic reticulum, nucleus, peroxisomes, and mitochondria and FeSOD that is not found in humans. $\mathrm{Cu}^{2+}$ and $\mathrm{Zn}^{2+}$ are required as enzyme stabilizers. SOD function to accelerate $\mathrm{O}_{2}$ dismutation and maintain balance between the amount of $\mathrm{O}_{2}$ and $\mathrm{H}_{2} \mathrm{O}_{2}$ formation (Rahmawati et al. 2014). The result of SOD activity measurement showed that SNEDDS ginger extract with eel fish oil at the same dose with pure ginger extract has higher SOD activity. This might be due to ginger extract in SNEDDS able to form nanometer-sized emulsion droplets distributed into digestive canal so that the effectiveness of compounds contained in ginger was more optimal. However, further tests are needed to determine whether the compound in the ginger extract can reach the target organ with a lipid-based delivery system using eel bone oil, so that the SNEDDS drug delivery system can be developed and become one of the most valuable drug compound delivery systems ( $\mathrm{He}$ et al. 2010).

In conclusion, phenolic content of ginger extract with $96 \%$ ethanol solvent which is $4.85 \mathrm{mg} / \mathrm{mL}$ equivalent with standard solution of gallic acid. Compounds contained in ginger have high antioxidant activity. In the antioxidant activity test using DPPH showed $\mathrm{IC}_{50}$ extract of pure ginger was higher than SNEDDS but in vivo test using adrenochrome assay to measure superoxide dismutase enzyme activity, SNEDDS activity was higher than other treatment groups.

\section{ACKNOWLEDGMENTS}

This study was supported by the Directorate General for Strengthening Research and Development, Community Service, Ministry of Research and Higher Education of the Republic of Indonesia.

\section{REFERENCES}

Ahmad A, Singhal U, Hossain MB, Islam N, Rizvi I. 2013. The role of the endogenous antioxidant enzymes and malondialdehyde in essential hypertension. J Clin Diagn Res 7 (6): 987-990.

Ahmad AR, Juwita, Ratulangi SR, Malik A. 2015. Penetapan Kadar Fenolik dan Flavonoid Total Ekstrak Metanol Buah dan Daun Patikala (Etlingera elatior (Jack) R.M.SM). Pharm Sci Res 2 (1): 110. [Indonesian]

Akinyemi JA, Ademiluyi AO, Oboh G. 2014. Inhibition of Angiotensin-1Converting enzyme activity by two varieties of ginger (Zingiber officinale) in rats fed a high cholesterol diet. J Med Food 17 (3): 317 323.

Baedah MA. 2010. Strategi Pengelolaan Ikan Sidat. DKP Sulawesi Tengah, Palu.

Christophersen PC, Christiansen ML, Holm R, Kristensen J, Jacobsen J, Abrahamsson B, Müllertz A. 2014. Fed and fasted state gastrointestinal in vitro lipolysis: In vitro in vivo relations of a conventional tablet, a SNEDDS and a solidified SNEDDS. Eur J Pharm Sci. 57: 232-239.

Chun OK, Kim DO, Lee CY. 2003. Superoxide radical scavenging activity of the mayor polyphenols in fresh plums. J Agric Food Chem 51 (27): 8067-8072.

Fatimah N, Sitomarang A, Fajar M. 2010. The test of antioxidant activity of the extract of ethanol $70 \%$ of rosella corolla (Hibiscus sabdariffa L.) based on the SOD activity and MDA concentration in red blood cells of the oxidative stressed sheep. Farmasains 1 (1): 18-24. [Indonesian]

Frenoux JMR, Prost ED, Belleville J, Prost J. 2001. A Polyunsaturated Fatty Acid Diet Lowers Blood Pressure and Improves Antioxidant Status in Spontaneously Hypertensive Rats. J Nutr 131: 39-45.

Harborne JB. 1998. Textbook of Phytochemical Methods. A Guide to Modern Techniques of Plant Analysis. 5th ed, Chapman and Hall Ltd, London.

He C. 2010. Effect of particle size and surface charge on cellular uptake and biodistribution of polymeric nanoparticles. Biomaterials 31: 3657-3666.

Inoue T, Okano K, Tsuruta Y, Tsuchiya K, Akiba T, Nitta K. 2015. Eicosapentaenoic Acid (EPA) Decrease the All-Cause Mortality in Hemodialysis Patients. Intern Med 54 (24): 3133-3137.

Juranek I, Bezek S. 2005. Controversy of free radical hypothesis: reactive oxygen species-cause or consequence of tissue injury? Gen Physiol Biophys 24: 263-278.

Kwon YS, Kim CM. 2003. Antioxidant constituent from the stem of Shorgum bicolor. Arch Pharm Res 26: 535-539.

Malik, A. Ahmad AR. 2015. Determination of phenolic and flavonoid contents of ethanolic extract of kanunang leaves (Cordia myxa L.). Intl J PharmTech Res 7 (2): 243-246.

Nicoll R, Henein MY. 2009. Ginger (Zingiber officinale Roscoe): A hot remedy for cardiovascular disease? Intl J Cardiol 131: 408-409.

Ong SLH, Vickers JJ, Zhang Y, McKenzie KUS, Walsh CE, Whitworth JA. 2007. Short communication role of xanthine oxidase in 
dexamethasone-induced hypertension in rats. Clin Exp Pharmacol Physiol 34: 517-519.

Patel MJ, Patel NM, Patel RB, Patel RP. 2010. Formulation and evaluation of self-microemulsifying drug delivery system of Lovastatin. Asian J Pharm Sci 5: 266-267.

Rahmawati G, Rachmawati F, winarsi H. 2014. Aktivitas Superoksida Dismutase Tikus Diabetes Yang Diberi Ekstrak Batang Kapulaga Dan Glibenklamid. Scripta Biologica (1): 197-201.
Rajkumar S, Praveen MR, Gajjar D, Vasavada AR, Alapure B, Patel D, Kapur S. 2008. Activity of superoxide dismutase isoenzymes in lens epithelial cells derived from different types of age-related cataract. J Cataract React Surg 34 (3): 470-474

Rovara O. 2010. Pemeliharaan Benih Ikan Sidat Teradaptasi di Kawasan Segara Anakan. Badan Pengkajian dan Penerapan Teknologi, Jakarta. [Indonesian] 